\title{
A Structured Literature Review on Obsolete Electric Vehicles Management Practices
}

\author{
Idiano D'Adamo ${ }^{1}$ (D) and Paolo Rosa ${ }^{2, *(D)}$ \\ 1 Department of Law and Economics, Unitelma Sapienza-University of Rome, Viale Regina Elena 295, \\ 00161 Roma, Italy; idiano.dadamo@unitelmasapienza.it \\ 2 Department of Management, Economics, and Industrial Engineering, Politecnico di Milano, \\ Piazza Leonardo da Vinci, 32, 20133 Milano, Italy \\ * Correspondence: paolo1.rosa@polimi.it; Tel.: +39-02-2399-9537
}

Received: 6 November 2019; Accepted: 2 December 2019; Published: 3 December 2019

\begin{abstract}
The use of electricity for transportation needs offers the chance to replace fossil fuels with greener energy sources. Potentially, coupling sustainable transports with Renewable Energies (RE) could reduce significantly both Greenhouse Gas (GHG) emissions and the dependency on oil imports. However, the expected growth rate of Electric Vehicles (EVs) could become also a potential risk for the environment if recycling processes will continue to function in the current way. To this aim, the paper reviews the international literature on obsolete EV management practices, by considering scientific works published from 2000 up to 2019. Results show that the experts have paid great attention to this topic, given both the critical and valuable materials embedded in EVs and their main components (especially traction batteries), by offering interesting potential profits, and identifying the most promising End-of-Life (EoL) strategy for recycling both in technological and environmental terms. However, the economics of EV recycling systems have not yet been well quantified. The intent of this work is to enhance the current literature gaps and to propose future research streams.
\end{abstract}

Keywords: obsolete electric vehicles; ELV management; circular economy; structured literature review

\section{Introduction}

The transportation sector is one of the main reasons for global warming. About one-third of the global energy demand and one-sixth of global Greenhouse Gas (GHG) emissions come from transport [1], mainly because of fossil fuels [2,3]. Given the increasing number of catastrophic events caused by climate changes, international institutions have decided to reconsider the way vehicles can move with a lower impact on the environment. Trying to answer to these trends, automotive manufacturers have been pushed towards the development of innovative technologies for the sustainable mobility of people and things [4,5], and this has also followed the circular economy concept [6,7]. Hence, Electric Vehicles (EVs) were developed under many forms, like BEVs (Battery Electric Vehicles), HEVs (Hybrid Electric Vehicles), PHEVs (Plug-in Hybrid Electric Vehicles), REEVs (Range Extended Electric Vehicles), FCEVs (Fuel Cell Electric Vehicles) and FCHEVs (Fuel Cell Hybrid Electric Vehicles). Each of them employs electricity in a different way in order to move [8,9]. Electric cars can be broadly classified into full electric and hybrid ones [10,11]. An EV moves only through an electric motor, whereas an HEV moves either with an electric motor or a conventional combustion motor. A battery stores the extra energy, by capturing it with regenerative braking systems. In a PHEV, the batteries can be loaded with additional grid electricity. In a REEV, either an internal combustion engine or the grid electricity charges the battery. A FCEV (or FCHEV) embeds a hydrogen tank and a fuel cell as a source of energy [12]. From a structural perspective, they can be considered a type of $\mathrm{HEV}$, in which the fuel cell replaces the 
internal combustion engine. Using atmospheric oxygen and compressed gaseous hydrogen supplied from the on-board tank, the fuel cell generates electricity, which powers the vehicle's electric motor [13].

According to the Global EV Outlook of the Electric Vehicle Initiative (EVI) and the International Energy Association (IEA), the global EVs exceeded 5.1 million in 2018, up 2 million from the previous year. China is the world's largest electric car market with 2.3 million units, followed by Europe (1.2 million units) and the USA (1.1 million units). This outlook defines the future global electric car sales in 2030 by considering two potential scenarios: 23 million units in the New Policies Scenario and 43 million units in the EV30@30 Scenario (Figure 1) [10].
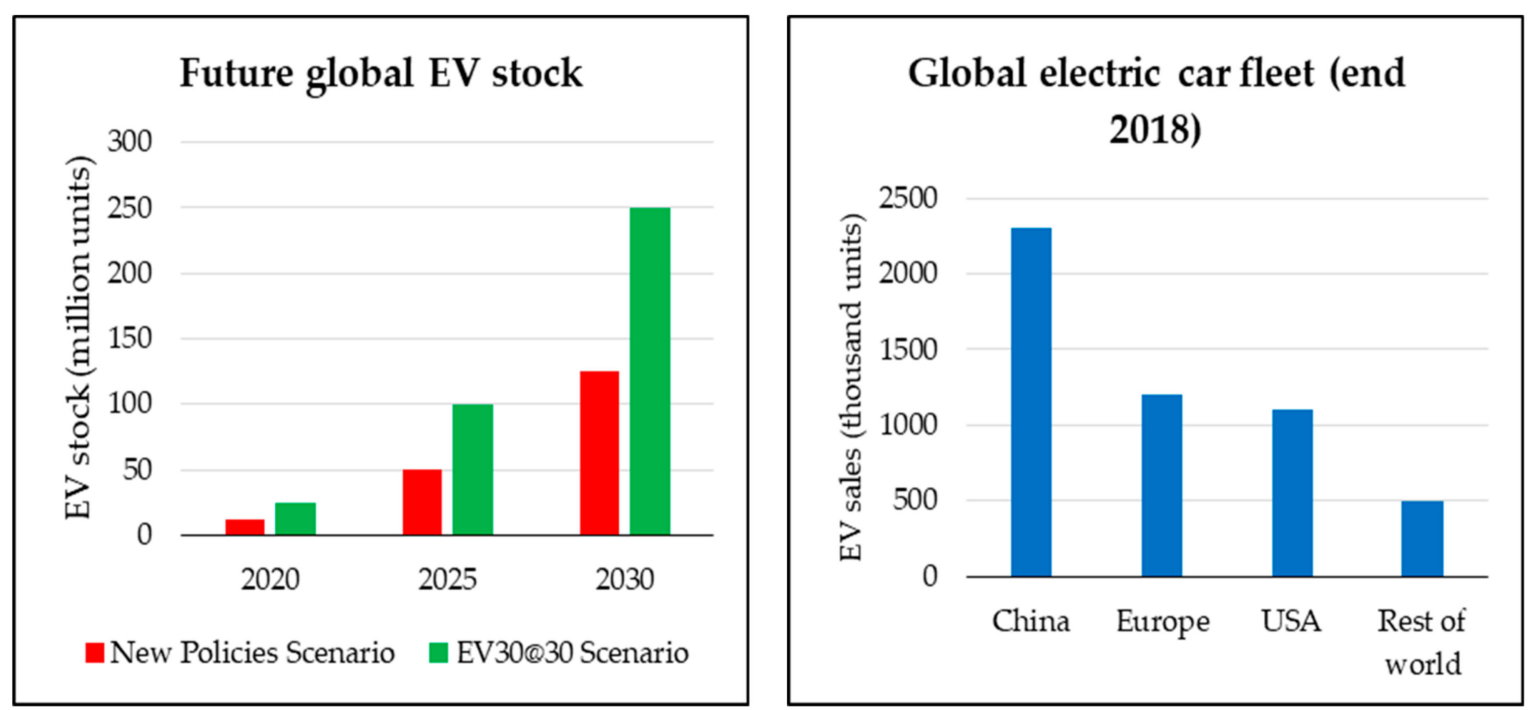

Figure 1. Global EV stock in 2020-2030 period and global EV sales in 2018 [10].

Several studies already assessed the higher sustainability of EVs compared with common Internal Combustion Engine Vehicles (ICEVs) [14-16]. However, EVs are not immune from criticism. Generally, their weight is higher than ICEVs (because of batteries, electric motors, power electronics, etc.), their range of action is limited and recharging infrastructures are lacking $[11,17,18]$. Furthermore, one of the most important issues related to EVs is that, given their higher complexity, they are very difficult to recycle [19-24]. In order to summarize the available knowledge and provide evidence for the main gaps that are still waiting for innovative answers, a structured literature review is proposed in this work.

The paper is organized as follows. Section 2 presents the topic conceptualization and classification, describes the research methodology and assesses the framework of analysis. Section 3 shows the literature review metrics adopted and proposes an overall view on results. Section 4 shows a discussion on the relevant topics analyzed by proposing a critical perspective. Finally, Section 5 presents some concluding remarks.

\section{Materials and Methods}

\subsection{Topic Conceptualization and Classification}

Renewable Energies (REs), sustainable transportation and waste management strategies have assumed a central role in the last decades, not only in theoretical terms, but also in practice $[25,26]$. Citizens, firms and governments are extremely interested in creating economic opportunities and preserving the environment. Their combination could potentially reduce the environmental impact of every human activity and offers interesting chances for new businesses [27]. Among waste management strategies, there is great attention paid towards recycling [28-31]. An assessment of the knowledge on EVs gives us the chance to put together all these points. 


\subsection{Research Methodology and Framework of Analysis}

In order to assess the whole knowledge on EVs, a systematic literature review was implemented. After a deep survey, a list of papers selected through the most popular scientific works search engines (e.g., Google ${ }^{\mathrm{TM}}$ Scholar, Web of Science ${ }^{\mathrm{TM}}$, Sage ${ }^{\mathrm{TM}}$, Science Direct ${ }^{\mathrm{TM}}$, Springer ${ }^{\mathrm{TM}}$, MDPI ${ }^{\mathrm{TM}}$, Emerald ${ }^{\mathrm{TM}}$, Scopus ${ }^{\mathrm{TM}}$, Taylor \& Francis ${ }^{\mathrm{TM}}$ Online and Wiley ${ }^{\mathrm{TM}}$ Online Libraries) have been evaluated [32]. All of the selected scientific documents have been published between 2000 and 2019. They have been provided by adopting a series of combinations of two keywords like "recycling" and "electric vehicle" that have been researched in the titles, abstracts and keywords of papers. After a deep reading of all the papers, a structured literature review was performed, and the main results are summarized below. The output of the searching process in terms of number of works published by year is proposed in Figure 2. The number of total documents $\left(n^{\circ} 171\right)$ reveals the considerable attention devoted to these topics, especially from 2015 onwards, with about $67 \%$ of documents concentrated between 2015 and 2019. Documents pertain to $n^{\circ} 100$ scientific journals with impact factor, $n^{\circ} 27$ scientific journals without impact factor, $n^{\circ} 28$ proceedings of scientific conferences, $n^{\circ} 10$ scientific reports, $n^{\circ} 4$ industrial reports and $\mathrm{n}^{\circ} 2$ book chapters.

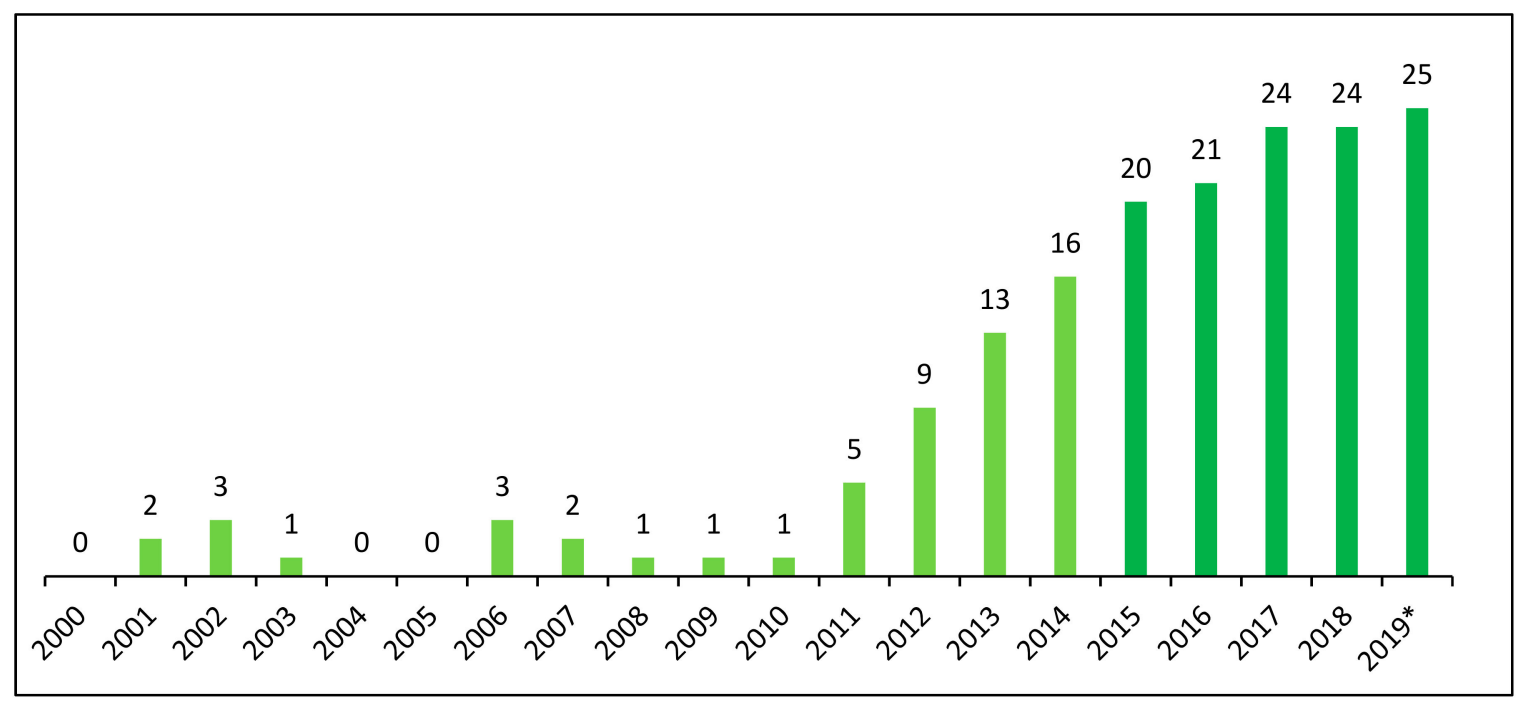

Figure 2. Historical series of published papers from 2000 up to 2019 (partial).

The growth trend reached its peak during the last year examined. The 2019 data are partial, but greater than the previous years. The last available data speak about a new record of EVs on the road, with a global EV stock of about 5.1 million vehicles in 2018, up 2 million from the previous year [10].

Figure 3 displays the geographical distribution of documents, where the institution of the first author was considered as reference. This distribution is concentrated in China, the USA and Germany. These countries cover about $50 \%$ of the total number of published articles. 


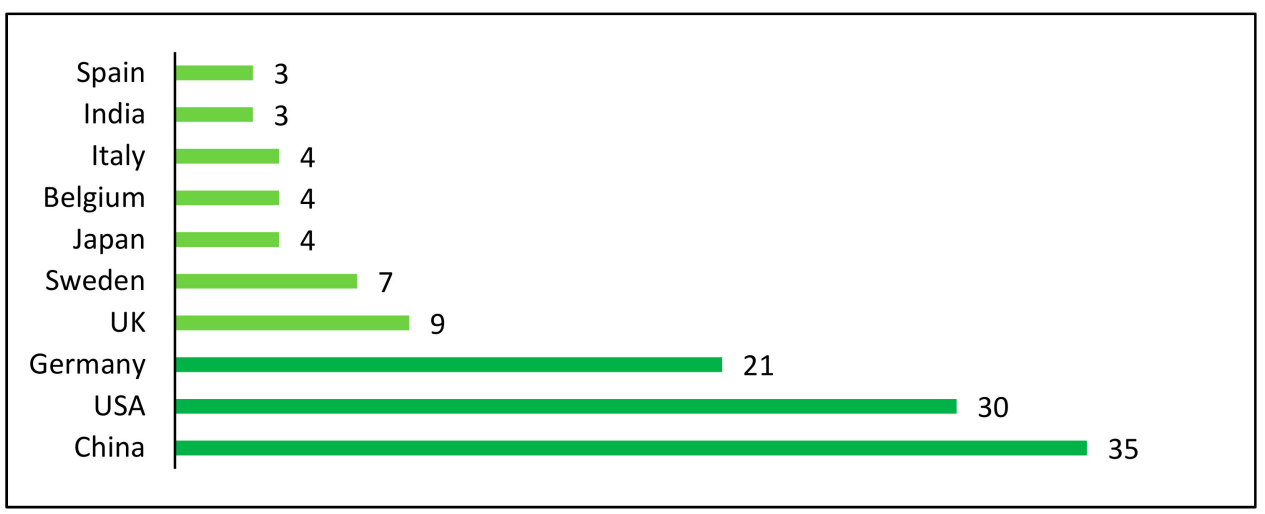

Figure 3. Geographical distribution of published papers.

China occupies the first position with $\mathrm{n}^{\circ} 35$ documents, followed by the USA with 30 documents, coinciding with their role in the automotive market. In fact, China was the global leader in EV manufacturing from 2016 onwards [33-35], while the USA occupied this role till 2015 [36]. Interestingly, Germany has a lower stock of EVs than other countries, but a high relevance in the European automotive sector and has a high involvement of the government towards the research and diffusion of EVs [37]. There are several perspectives from which EVs and recycling were addressed by the literature (Figure 4) [38]. In macroscopic terms, the EV End-of-Life (EoL) strategy is the most discussed topic. Among these strategies, recycling is the best solution ( ${ }^{\circ} 52$ documents). The second most discussed topic is the environmental evaluation of $\mathrm{EVs}$ ( $\mathrm{n}^{\circ} 40$ documents), performed to underline the advantages of moving towards sustainable goals [39], while the economic and social benefits of EV recycling are not well assessed by the experts. In addition, several authors dedicated great attention to a specific EV component (batteries) [40].

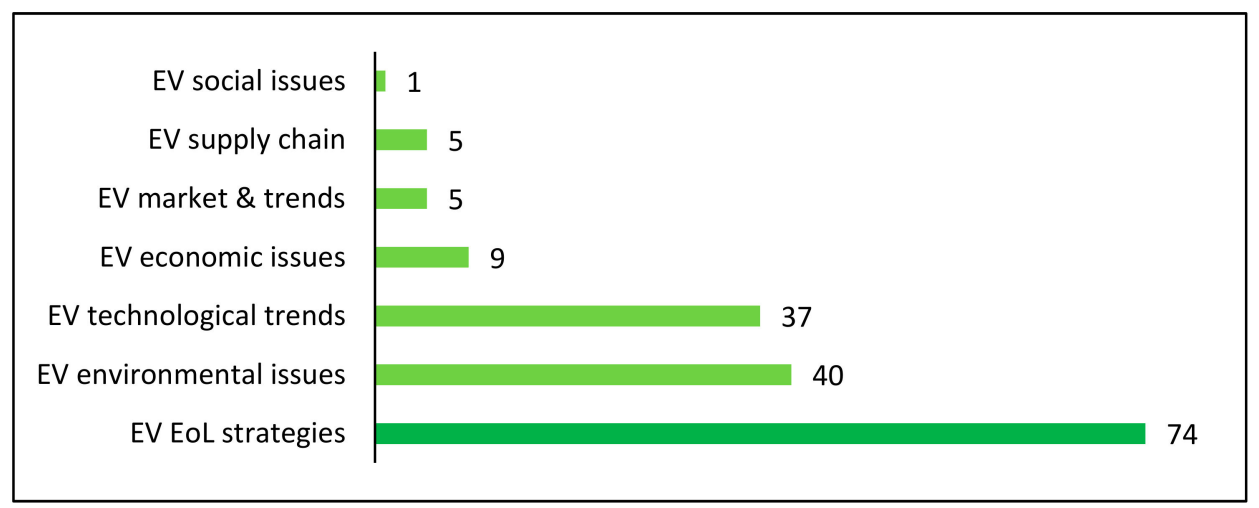

Figure 4. Macro topics of published papers.

The analysis of macro topics highlights that research on EVs follow a multidisciplinary strategy. About the research methodology, it is broadly based on the analytical approach ( ${ }^{\circ} 129$ documents). Theoretical, survey and case studies are very limited, with 37, 3 and 2 documents, respectively. In the following section, each macro topic is discussed in detail.

\section{Results}

The structured literature review showed that articles pertaining to the obsolete EV management practices could be classified in three types:

- Works on EV disassembly (see Section 3.1);

- Works on EV recycling (and reuse, just for batteries)—(see Section 3.2);

- Works on EV remanufacturing (see Section 3.3). 
In addition, considering only EV recycling, the three pillars of sustainability are explored as well:

- Works on EV recycling environmental issues (see Section 3.4);

- Works on EV recycling economic issues (see Section 3.5);

- Works on EV recycling social issues (see Section 3.6).

\subsection{EV Disassembly}

When considering a traditional ELV dismantling process, disassembly is the second activity, after fluids and hazardous systems decontamination, done by car dismantlers on obsolete vehicles. It represents a high value stage for car dismantlers, given that disassembled components (if in good conditions) can usually be resold as spare parts on the secondary market. For EV disassembly, the main elements taken into account by experts are batteries, electric engines and power electronics (see Table 1).

Table 1. Focus of EV disassembly-oriented papers.

\begin{tabular}{cccc}
\hline Author & Battery & Engine & Electronics \\
\hline$[41]$ & $\mathrm{x}$ & & \\
{$[42]$} & $\mathrm{x}$ & $\mathrm{x}$ & \\
{$[43]$} & & & $\mathrm{x}$ \\
{$[44]$} & & & $\mathrm{x}$ \\
\hline 45$]$ & & & \\
\hline
\end{tabular}

For the batteries, disassembly is done (after discharging) immediately before either recycling or remanufacturing. Given the lack of information in product variants, battery disassembly is done manually. Only two examples have been found in literature [41,42]. Here, the authors present a concept for a battery disassembly workstation where operators are assisted by robots. While persons perform more complex tasks, robots perform simple and repetitive tasks, such as removing screws and bolts from cases. A similar approach is proposed also by [43], but focusing on EV electric engines.

Finally, other experts focus on power electronics [44,45]. Here, a robotized workstation is proposed for the automatic disassembly of electronic components from EV batteries before their final recycling. An identification of the profitability of recycling such electronic components is also provided.

One of the first steps of EoL management is disassembly, typically requiring several time/cost consuming processes. It depends on the costs and risks related to the ability to separate the sub-components from the whole product as to whether disassembly is viable or not. From a technological point of view, manual procedures are usually adopted, explaining the low number of papers focusing on this topic.

\subsection{EV Recycling}

The EVs market is one of the most interesting fields from the recycling point of view. A generic EV embeds lots of key materials (almost $25 \mathrm{~kg}$ per car) inside different subsystems and components, offering great recycling potentials. Some important examples are represented by traction batteries, electric drive motors and power electronics [46]. The production of electric cars is expected to grow rapidly, reaching 20 million cars by 2020 [36]. By assuming a mean life of a car of 10 years, there will be an enormous amount of EVs to be recycled by 2030. From these data, it is clear that the strategic importance can be assumed by a preventive decision about alternative sustainable treatments for this waste flow. In particular, the use of industrial symbiosis can minimize material wastage and environmental burdens [23]. A comparison among recycling methods is proposed by some authors [47], in which the final result defines the role of recycling policies that aim to incentivize battery collection and emissions reductions (Table 2). 
Table 2. Focus of EV recycling-oriented papers.

\begin{tabular}{|c|c|c|c|c|}
\hline Author & Battery (Reuse/Recycle) & Magnets & Electronics & Fuel Cells \\
\hline [48] & $x$ & & & \\
\hline [49] & $\mathrm{x}$ & & & \\
\hline [50] & $x$ & & & \\
\hline [51] & $x$ & & & \\
\hline [52] & $x$ & & & \\
\hline [53] & $x$ & & & \\
\hline [54] & $x$ & & & \\
\hline [55] & $\mathrm{x}$ & & & \\
\hline [18] & $x$ & & & \\
\hline [42] & $x$ & & & \\
\hline [56] & $x$ & & & \\
\hline [57] & $x$ & & & \\
\hline [21] & $x$ & & & \\
\hline [58] & $x$ & & & \\
\hline [50] & $\mathrm{x}$ & & & \\
\hline [59] & $x$ & & & \\
\hline [60] & $x$ & & & \\
\hline [61] & $x$ & & & \\
\hline$[62]$ & $x$ & & & \\
\hline [63] & $x$ & & & \\
\hline [64] & $x$ & & & \\
\hline$[65]$ & $x$ & & & \\
\hline$[66]$ & $x$ & & & \\
\hline$[67]$ & $x$ & & & \\
\hline [68] & $x$ & & & \\
\hline [69] & $x$ & & & \\
\hline [70] & $x$ & & & \\
\hline [71] & $x$ & & & \\
\hline [72] & $x$ & & & \\
\hline [73] & $x$ & & & \\
\hline [42] & $x$ & & & \\
\hline [74] & $x$ & & & \\
\hline [75] & & $x$ & & \\
\hline [76] & & $x$ & & \\
\hline [77] & & $x$ & & \\
\hline [78] & & $x$ & & \\
\hline [79] & & $x$ & & \\
\hline [80] & & $x$ & & \\
\hline [46] & & & $x$ & \\
\hline [81] & & & $x$ & \\
\hline [82] & & & & $x$ \\
\hline [13] & & & & $x$ \\
\hline
\end{tabular}

Recycling is an opportunity to close the loop of EVs, which aims to reach sustainability goals. However, specific recycling pillars are proposed in the next sub-sections. One of the main results from this review is the significant number of papers focusing on this EoL option. Certainly, reuse is a better solution in terms of the waste hierarchy, but it is not always feasible from a technical point of view. Recycling processes, instead, are suitable to satisfy the circular economy model. Material circularity requires the development of secondary markets where critical and special metals can re-enter in the raw materials cycle. As the authors express, in order to support this development, the economic side must be always taken into account when new technological options are selected. 


\subsubsection{EV Battery Recycling}

The EoL management of EV batteries is one of the most discussed issues in literature. Broadly speaking, EoL strategies can be distinguished in three categories: reuse, remanufacturing and recycling. Literature works are focused on the pros and cons related to each battery technology from both technical, environmental and economic perspective [83-86]. Other authors focus on both a kind of technology (usually Li-ion) and the management of materials embedded in batteries [87-90] (Tables 3-5). Considering the economic perspective, the cost of EV batteries plays a critical role in determining the commercial viability of EVs, not only during their usage, but also at the end of their useful life. Spent batteries maintain a relevant market value as manufacturers can extract critical materials from key components (e.g., cells and power electronics), typically through hydrometallurgical processes. This topic is investigated from multiple perspectives in literature (see Table 2).

Table 3. Focus of EV battery reuse-oriented papers.

\begin{tabular}{cccc}
\hline Author & Environmental & Economic & Technical \\
\hline$[48]$ & $\mathrm{x}$ & $\mathrm{x}$ & \\
{$[49]$} & & $\mathrm{x}$ & \\
{$[50]$} & $\mathrm{x}$ & \\
{$[51]$} & & $\mathrm{x}$ \\
{$[52]$} & & $\mathrm{x}$ \\
\hline 53$]$ & & & \\
\hline
\end{tabular}

Table 4. Focus of EV battery recycling-oriented papers.

\begin{tabular}{cccc}
\hline Author & Current State & Predictions & Technologies \\
\hline$[54]$ & $\mathrm{x}$ & & \\
{$[55]$} & $\mathrm{x}$ & & \\
{$[18]$} & $\mathrm{x}$ & $\mathrm{x}$ & \\
{$[42]$} & $\mathrm{x}$ & $\mathrm{x}$ & \\
{$[56]$} & & $\mathrm{x}$ & \\
{$[57]$} & $\mathrm{x}$ & \\
{$[21]$} & $\mathrm{x}$ & \\
{$[58]$} & & $\mathrm{x}$ \\
{$[50]$} & & $\mathrm{x}$ \\
{$[59]$} & & $\mathrm{x}$ \\
{$[60]$} & & $\mathrm{x}$ \\
{$[61]$} & & $\mathrm{x}$ \\
{$[62]$} & & $\mathrm{x}$ \\
{$[63]$} & & $\mathrm{x}$ \\
{$[64]$} & & $\mathrm{x}$ \\
{$[65]$} & & $\mathrm{x}$ \\
{$[66]$} & & $\mathrm{x}$ \\
{$[67]$} & & $\mathrm{x}$ \\
{$[68]$} & & $\mathrm{x}$ \\
{$[69]$} & & $\mathrm{x}$ \\
{$[70]$} & & $\mathrm{x}$ \\
{$[71]$} & & $\mathrm{x}$ \\
{$[72]$} & & $\mathrm{x}$ \\
{$[73]$} & & $\mathrm{x}$ \\
{$[42]$} & & \\
{$[74]$} & & \\
\end{tabular}


Table 5. Technologies supporting EV battery recycling processes.

\begin{tabular}{ccccc}
\hline Author & Hydrometallurgy & Biometallurgy & Mechanical & Mixed \\
\hline$[59]$ & $\mathrm{x}$ & & & \\
{$[60]$} & $\mathrm{x}$ & & & \\
{$[61]$} & $\mathrm{x}$ & & & \\
{$[62]$} & $\mathrm{x}$ & & & \\
{$[63]$} & $\mathrm{x}$ & & & \\
{$[64]$} & $\mathrm{x}$ & & & \\
{$[65]$} & $\mathrm{x}$ & & & \\
{$[66]$} & $\mathrm{x}$ & & & \\
{$[67]$} & $\mathrm{x}$ & & & \\
{$[68]$} & $\mathrm{x}$ & & & \\
{$[69]$} & $\mathrm{x}$ & & & \\
{$[70]$} & & $\mathrm{x}$ & & \\
{$[71]$} & & $\mathrm{x}$ & & \\
{$[72]$} & & & & \\
{$[73]$} & & & & \\
{$[42]$} & & & & \\
{$[74]$} & & & & \\
\hline
\end{tabular}

One way to manage obsolete EV batteries is represented by reuse. Given the short lifetime of an EV battery (quantified by many experts as 8-10 years-or the period where the battery capacity reduces to $80 \%$ of the original one), their reuse is seen by experts as a reasonable and sustainable strategy, before opting to recycle [48]. Better performances can be obtained by reusing EV batteries together with Renewable Energy (RE) sources in stationary applications. Because of this, several business perspective are proposed in the literature, either under the form of Product-Service Systems (PSSs) [49], dedicated EU regulations [50] or are considered industrial symbiosis [51]. However, the most effective way to manage obsolete EV batteries seems to be a combination of both reuse and recycling practices [52,53].

Several papers have been written about EV battery recycling in the last decades. In general terms, EV battery recycling follows the same process exploited for recovering any type of e-waste, with disassembly, shredding, separation and refining as the main process steps. Depending on the technologies employed during refining (chemical or mechanical ones), it is possible to reach different material recovery performances.

From the current state of the art perspective on EV battery recycling, some works are available in literature, but none of them consider this topic in a broad perspective. Some experts focus on the EV battery design stage by considering the economic and environmental strategies supporting the sustainable treatment of these products [54]. Others follow the same logic, but focus on either a specific type of EV battery [55], national context [18] or recycling method [42].

From the prediction perspective, the focus is on critical materials embedded into EV batteries, either in terms of current availabilities, projected mining capacity or forecasted demands [56]. These assessments are usually presented under the form of decision-support tools [57] or generic simulation platforms [21]. Finally, other experts assess the introduction of EV batteries recycling on current ELV regulations by taking as reference either the Umicore battery recycling process [58] or the Chinese context [50].

From a technological perspective, EV battery recycling is a well-assessed topic in literature, with a prevalent role for the hydrometallurgical process, given its high performances in terms of materials recovery. Some authors describe it through a review on the evolution of chemical recovery technologies $[59,60]$. Others prefer to focus on either a specific chemical process $[61,69]$, separation processes [66-68], EV battery type [62], leaching agent [63] or recovered material [64,65]. A promising sub-category of hydrometallurgical processes is represented by biological ones. However, only two works have been found in literature on this topic, and both of them focus 
on organic leaching agents $[70,71]$. The mechanical process is another way to recover EV batteries. However, in this case, only two works have been found in literature [72,73]. Finally, other experts put together both chemical and mechanical processes, by employing all their benefits [42,74].

\subsubsection{EV Magnet Recycling}

After EV batteries, EV magnets are the second element discussed in literature. Several works present innovative ways to recover Rare Earth Elements (REEs) from obsolete magnets, either coming from mixed sources [75] or specific waste streams (including magnets from HEVs) [76-78]. Other works quantify present and future amounts of recovered REEs from specific HEV components [79]. Finally, different recycling approaches for recycling magnets from HEVs are compared [80].

\subsubsection{EV Power Electronics Recycling}

As evidenced by the authors many times for common ELVs, in the similar case of EVs, the recovery of electronic components is still in its infancy [46]. Even if electronics in EVs are even more present than in ICEVs, neither industry, nor politics, nor scientists consider its recovery to be an important issue, preferring to focus on batteries (see the previous Sections 3.2 and 3.2.1). The only paper found in literature on this topic compares, both in economic and environmental impact terms, two different ways to recycle EV power electronics, by exploiting either traditional ELV recovery processes or coupling them to a dedicated plant [81].

\subsubsection{Fuel Cells Recycling}

Another focus related to EVs is the recycling of fuel cells. Given the difficulty of the BEV's ability to cover long distances, FCEVs will surely take part of the market in future car sales. This way, a percentage of future obsolete EVs will be constituted by FCEVs. Unfortunately, also in this case, only two articles have been found in literature. The first one assesses the effects of a probable update of the current EU ELV Directive towards the recovery of fuel cells [82]. The second one investigates the potential contribution offered by the recycling of FCEVs for meeting the current platinum demand of Europe [13].

\subsection{EV Remanufacturing}

The remanufacturing of components coming from obsolete cars is a well-assessed business. However, from an EV perspective, the literature considers of only EV battery remanufacturing. Considering the few papers focusing on that, EV battery remanufacturing is discussed in terms of either overall process [91], economic performances (compared with reuse/recycling ones) [92,93] or real application cases [94].

\subsection{EV Environmental Issues}

The diffusion of EV technologies is strictly related with energy storage technologies [95]. This way, the environmental analysis has been historically focused on the use phase of EVs. However, many components of EVs (e.g., electronics, magnets and batteries) embed critical raw materials. In this way, experts have started to assess the positive environmental impact associated with EV recycling (as a more sustainable alternative than landfilling), both in terms of GHG emissions reduction [20], electricity mix generation technologies [96], secondary resources recovery (specifically REEs [97], critical metals [12] and lithium [98]) and policy measures that ensure the availability of materials [33].

\subsection{EV Economic Issues}

An important result coming from the present work is that economic issues of EV recycling systems are not well assessed. In particular, the following gaps have been evidenced [99]: 
- Scarcity of studies assessing the potential value of different EV battery technologies $[100,101]$;

- Low EV battery recycling rates given the focus of recycling plants on high-volumes [102];

- Translation of expected environmental benefits into real economic benefits [103].

\subsection{EV Social Issues}

Social issues related with EVs are rarely assessed by the experts, mainly in terms of the social influence on eco-innovation adoption. For this topic, just one paper [104] underlined the importance of interpersonal social influence, opinion leadership and personal norms on eco-innovation adoption.

\section{Discussion}

Satisfying human needs in the most sustainable way (and without further impacting the climate) is the greatest challenge of the $21^{\text {st }}$ century. The experts demonstrated in several works that both renewable energies and waste management strategies (either individually or together) can guarantee improvements in this sense [105-107]. Obsolete EV management practices represent a good example because several types of data (e.g., EV configurations, battery energy sources, electrical machines, charging systems, optimization techniques) are required [108,109].

From one side, EVs represent the answer of car manufacturers towards international directives that, for decades, have been asking for greener and more sustainable vehicles $[34,110,111]$. Hence, their reuse, remanufacturing and recycling is considered by many authors as a potential solution to several environmental challenges, like resource scarcity, sustainable economic growth and waste management $[112,113]$. From this side, some quantitative analyses are available $[114,115]$. However, given the great uncertainty related with either global volumes (see Table 1 for details), growth rates and the general evolution of the EV market, it is very difficult to have reliable estimates, even by adopting the most advanced simulation tools $[116,117]$. Therefore, none of the most recent works on ELVs investigate how EVs could influence future ELV trends. These data are of utmost importance not only for car manufacturers, but also for policymakers [118]. Based on these data, industries (especially those involved at EoL stage) could decide how to improve their plants' recovery performances, especially for low-volume materials. Instead, politicians could monitor illegal ELV flows and sustain the EV market expansion through optimized subsidy policies.

From a second perspective, the management of EV components (e.g., batteries, electric motors and electronic components) presents some knowledge gaps. The literature is full of articles considering batteries and electric motors to be promising components worth recycling [119]. However, power electronics could also increase the overall profitability, but few works assessed and quantified it $[120,121]$. This way, current recycling technologies must be improved if companies involved in ELV reverse logistic chains are willing to gather the highest profit from EVs [122-125]. Contrarily, the risk is the same encountered by companies when managing electronic components of ICEVs. Also, this change will be needed in terms of a legislative re-thinking of current regulations and procedures, by offering a concrete support to actors willing to enter into current ELV recovery chains [126]. Here, innovative directives, environmental requirements and technologies able to manage obsolete EVs are urgently needed [127].

From a third perspective, recycled metals represent the most interesting source of both economic and environmental benefits, given the huge amounts embedded in EVs. However, limiting the recycling process to cathode materials will play a negative effect on the EV battery recycling economics and the environmental impact [128]. This way, neither reward-penalty mechanisms nor subsidy policies will be sufficient [129]. The only way to increase profitability will be to consider the most valuable elements embedded in EVs, like power electronics and magnets.

Results coming from the work underlined, like the adoption of new technologies, can increase the efficiency and effectiveness of entire recycling processes towards more sustainable practices. At the same time, economic aspects related to recycling processes seem to not be well analyzed by the literature, and the main variables affecting their profitability are not well understood. These elements, 
together with the break-even point expressed in terms of the number of ELVs recycled per year, represent some interesting research areas for the future.

\section{Conclusions}

Currently, automotive manufacturers are investing big amounts of money on EVs, and the market is characterized by big growth trends and economic opportunities. However, environmental advantages could be obtained only if EVs can be really green, either in terms of the type of energy source exploited (i.e., powered by RE sources) or by considering different EoL strategies and by following the circular economy paradigm. From this last perspective, the current work shows lots of papers studying new ways to recycle EVs. Some of them are focused on the disassembly of whole cars, some on reuse of the components, some on reverse logistic chains and others on remanufacturing of components. However, lots of experts focus on EV battery recycling, especially Li-ion ones. Given their weight and content in critical materials, a battery is considered to be one of the prevalent elements to recover from EVs. However, we think that EVs can present other interesting components that are worth recycling, usually not considered by both scientific and industrial experts.

In order to avoid what currently happens during the recycling of ICEVs, the present paper wanted to assess the existing literature on EV recycling, trying to evidence current lacks in knowledge and to open issues for potential improvements. They can be summarized in: (i) limited estimates of future ELV streams, (ii) limited assessment of relations among stakeholders within the reverse logistic chain, (iii) limited studies on economic issues, (iv) absence of social analyses and (v) limited case studies considering the three sustainability pillars together.

Results highlight six considerations: (i) the topic is multidisciplinary and actual; (ii) economic evaluation is needed to develop the ELV recycling sector; (iii) the role of power electronics is not investigated into detail; (iv) the applicability of Circular Economy (CE) models on ELVs is feasible; (v) the pivotal role of recycling activities within CE models is verified and (vi) both waste management and renewable energy management can support the development of sustainable activities.

Author Contributions: Conceptualization, I.D. and P.R.; methodology, I.D. and P.R.; formal analysis, I.D.; data curation, P.R.; writing-original draft preparation, I.D. and P.R.; writing-review and editing, I.D. and P.R.; visualization, I.D.; supervision, P.R.

Funding: This research received no external funding.

Conflicts of Interest: The authors declare no conflict of interest.

\section{Acronyms}

$\begin{array}{llll}\text { BEV } & \text { Battery Electric Vehicle } & \text { GHG } & \text { Greenhouse Gas } \\ \text { CE } & \text { Circular Economy } & \text { HEV } & \text { Hybrid Electric Vehicle } \\ \text { ELV } & \text { End of Life Vehicles } & \text { ICEV } & \text { Internal Combustion Engine Vehicle } \\ \text { EoL } & \text { End of Life } & \text { IEA } & \text { International Energy Association } \\ \text { ESS } & \text { Energy Storage System } & \text { LIB } & \text { Lithium Ion Battery } \\ \text { EU } & \text { European Union } & \text { PCB } & \text { Printed Circuit Board } \\ \text { EV } & \text { Electric Vehicle } & \text { PHEV } & \text { Plug-in Hybrid Electric Vehicle } \\ \text { EVI } & \text { Electric Vehicle Initiative } & \text { RE } & \text { Renewable Energy } \\ \text { FCEV } & \text { Fuel Cell Electric Vehicle } & \text { REE } & \text { Rare Earth Elements } \\ \text { FCHEV } & \text { Fuel Cell Hybrid Electric Vehicle } & \text { REEV } & \text { Range Extended Electric Vehicle }\end{array}$

\section{References}

1. IRENA. Biogas for Road Vehicles Technologu Brief; IRENA: Abu Dhabi, UAE, 2018.

2. Tan, X.; Zeng, Y.; Gu, B.; Wang, Y.; Xu, B. Scenario Analysis of Urban Road Transportation Energy Demand and GHG Emissions in China-A Case Study for Chongqing. Sustainability 2018, 10, 2033. [CrossRef]

3. Lu, M.; Xie, R.; Chen, P.; Zou, Y.; Tang, J. Green Transportation and Logistics Performance: An Improved Composite Index. Sustainability 2019, 11, 2976. [CrossRef] 
4. Martin, M.; Røyne, F.; Ekvall, T.; Moberg, Å. Life cycle sustainability evaluations of bio-based value chains: Reviewing the indicators from a Swedish perspective. Sustainability 2018, 10, 547. [CrossRef]

5. Sovacool, B.K.; Kester, J.; Heida, V. Cars and kids: Childhood perceptions of electric vehicles and sustainable transport in Denmark and the Netherlands. Technol. Forecast. Soc. Chang. 2019, 144, 182-192. [CrossRef]

6. Saidani, M.; Yannou, B.; Leroy, Y.; Cluzel, F. Heavy vehicles on the road towards the circular economy: Analysis and comparison with the automotive industry. Resour. Conserv. Recycl. 2018, 135, 108-122. [CrossRef]

7. Fuso Nerini, F.; Slob, A.; Engström, R.E.; Trutnevyte, E. A Research and Innovation Agenda for Zero-Emission European Cities. Sustainability 2019, 11, 1692. [CrossRef]

8. Álvarez Fernández, R. A more realistic approach to electric vehicle contribution to greenhouse gas emissions in the city. J. Clean. Prod. 2018, 172, 949-959. [CrossRef]

9. Zhang, Y.; Han, Q. Development of electric vehicles for China's power generation portfolio: A regional economic and environmental analysis. J. Clean. Prod. 2017, 162, 71-85. [CrossRef]

10. IEA. Global EV Outlook 2019—Scaling-Up the Transition to Electric Mobility; IEA: London, UK, 2019.

11. EEA. Electric Vehicles in Europe; EEA: Copenhagen, Denmark, 2016.

12. Grandell, L.; Lehtilä, A.; Kivinen, M.; Koljonen, T.; Kihlman, S.; Lauri, L.S. Role of critical metals in the future markets of clean energy technologies. Renew. Energy 2016, 95, 53-62. [CrossRef]

13. Wittstock, R.; Pehlken, A.; Wark, M. Challenges in Automotive Fuel Cells Recycling. Recycling 2016, 1, 343-364. [CrossRef]

14. Lave, L.B.; MacLean, H.L. An environmental-economic evaluation of hybrid electric vehicles: Toyota's Prius vs. its conventional internal combustion engine Corolla. Transp. Res. Part D Transp. Environ. 2002, 7, 155-162. [CrossRef]

15. Offer, G.J.; Howey, D.; Contestabile, M.; Clague, R.; Brandon, N.P. Comparative analysis of battery electric, hydrogen fuel cell and hybrid vehicles in a future sustainable road transport system. Energy Policy 2010, 38, 24-29. [CrossRef]

16. Correa, G.; Muñoz, P.; Falaguerra, T.; Rodriguez, C.R. Performance comparison of conventional, hybrid, hydrogen and electric urban buses using well to wheel analysis. Energy 2017, 141, 537-549. [CrossRef]

17. Graditi, G.; Langella, G.; Laterza, C.; Valenti, M. Conventional and electric vehicles: A complete economic and environmental comparison. In Proceedings of the ICCEP 2015-5th International Conference on Clean Electrical Power: Renewable Energy Resources Impact, Taormina, Italy, 16-18 June 2015; pp. 660-665.

18. Wang, W.; Wu, Y. An overview of recycling and treatment of spent LiFePO4 batteries in China. Resour. Conserv. Recycl. 2017, 127, 233-243. [CrossRef]

19. Manzetti, S.; Mariasiu, F. Electric vehicle battery technologies: From present state to future systems. Renew. Sustain. Energy Rev. 2015, 51, 1004-1012. [CrossRef]

20. Hao, H.; Qiao, Q.; Liu, Z.; Zhao, F. Impact of recycling on energy consumption and greenhouse gas emissions from electric vehicle production: The China 2025 case. Resour. Conserv. Recycl. 2017, 122, 114-125. [CrossRef]

21. Tang, Y.; Zhang, Q.; Li, Y.; Wang, G.; Li, Y. Recycling Mechanisms and Policy Suggestions for Spent Electric Vehicles' Power Battery -A Case of Beijing. J. Clean. Prod. 2018, 186, 388-406. [CrossRef]

22. Larcher, D.; Tarascon, J.-M. Towards greener and more sustainable batteries for electrical energy storage. Nat. Chem. 2015, 7, 19-29. [CrossRef]

23. Mathur, N.; Deng, S.; Singh, S.; Yih, Y. Evaluating the environmental benefits of implementing Industrial Symbiosis to used electric vehicle batteries. Procedia CIRP 2019, 80, 661-666. [CrossRef]

24. Qiao, Q.; Zhao, F.; Liu, Z.; He, X.; Hao, H. Life cycle greenhouse gas emissions of Electric Vehicles in China: Combining the vehicle cycle and fuel cycle. Energy 2019, 177, 222-233. [CrossRef]

25. Rosa, P.; Terzi, S. Comparison of current practices for a combined management of printed circuit boards from different waste streams. J. Clean. Prod. 2016, 137, 300-312. [CrossRef]

26. Singlitico, A.; Goggins, J.; Monaghan, R.F.D. The role of life cycle assessment in the sustainable transition to a decarbonised gas network through green gas production. Renew. Sustain. Energy Rev. 2019, 99, 16-28. [CrossRef]

27. Zeng, X.; Li, J.; Liu, L. Solving spent lithium-ion battery problems in China: Opportunities and challenges. Renew. Sustain. Energy Rev. 2015, 52, 1759-1767. [CrossRef]

28. Cucchiella, F.; D’Adamo, I.; Rosa, P.; Terzi, S. Automotive printed circuit boards recycling: An economic analysis. J. Clean. Prod. 2016, 121, 130-141. [CrossRef] 
29. D'Adamo, I.; Rosa, P.; Terzi, S. Challenges in waste electrical and electronic equipment management: A profitability assessment in three European countries. Sustainability 2016, 8, 633. [CrossRef]

30. Amato, A.; Becci, A.; Birloaga, I.; De Michelis, I.; Ferella, F.; Innocenzi, V.; Ippolito, N.M.; Pillar Jimenez Gomez, C.; Vegliò, F.; Beolchini, F. Sustainability analysis of innovative technologies for the rare earth elements recovery. Renew. Sustain. Energy Rev. 2019, 106, 41-53. [CrossRef]

31. Cheng, C.; Lin, C.; Wen, L.; Chang, T. Determining environmental costs: A challenge in a governmental e-waste recycling scheme. Sustainability 2019, 11, 5156. [CrossRef]

32. Webster, J.; Watson, R.T. Analyzing the Past to Prepare for the Future: Writing a Literature Review. MIS Q. 2002, 26, xiii-xiii.

33. Du, J.; Ouyang, M.; Chen, J. Prospects for Chinese electric vehicle technologies in 2016-2020: Ambition and rationality. Energy 2017, 120, 584-596. [CrossRef]

34. Zhang, X.; Liang, Y.; Yu, E.; Rao, R.; Xie, J. Review of electric vehicle policies in China: Content summary and effect analysis. Renew. Sustain. Energy Rev. 2017, 70, 698-714. [CrossRef]

35. IEA. Global EV Outlook 2016-Beyond One Million Electric Cars; IEA: London, UK, 2016.

36. IEA. Global EV Outlook 2017-Two Million and Counting; IEA: London, UK, 2017.

37. Wolff, S.; Madlener, R. Driven by change: Commercial drivers' acceptance and efficiency perceptions of light-duty electric vehicle usage in Germany. Transp. Res. Part C Emerg. Technol. 2019, 105, 262-282. [CrossRef]

38. Zeng, X.; Duan, H.; Wang, F.; Li, J. Examining environmental management of e-waste: China's experience and lessons. Renew. Sustain. Energy Rev. 2017, 72, 1076-1082. [CrossRef]

39. Choma, E.F.; Ugaya, C.M.L. Environmental impact assessment of increasing electric vehicles in the Brazilian fleet. J. Clean. Prod. 2017, 152, 497-507. [CrossRef]

40. Peters, J.F.; Baumann, M.; Zimmermann, B.; Braun, J.; Weil, M. The environmental impact of Li-Ion batteries and the role of key parameters-A review. Renew. Sustain. Energy Rev. 2017, 67, 491-506. [CrossRef]

41. Wegener, K.; Andrew, S.; Raatz, A.; Dröder, K.; Herrmann, C. Disassembly of electric vehicle batteries using the example of the Audi Q5 hybrid system. Procedia CIRP 2014, 23, 155-160. [CrossRef]

42. Zhang, J.; Li, B.; Garg, A.; Liu, Y. A generic framework for recycling of battery module for electric vehicle by combining the mechanical and chemical procedures. Int. J. Energy Res. 2018, 42, 3390-3399. [CrossRef]

43. Bdiwi, M.; Rashid, A.; Putz, M. Autonomous disassembly of electric vehicle motors based on robot cognition. In Proceedings of the ICRA 2016 -IEEE International Conference on Robotics and Automation; IEEE: Stockholm, Sweden, 2016; pp. 2500-2505.

44. Li, J.; Barwood, M.; Rahimifard, S. Robotic disassembly for increased recovery of strategically important materials from electrical vehicles. Robot. Comput. Integr. Manuf. 2018, 50, 203-212. [CrossRef]

45. Li, J.; Barwood, M.; Rahimifard, S. An automated approach for disassembly and recycling of Electric Vehicle components. In Proceedings of the IEVC 2014-IEEE International Electric Vehicle Conference, Florence, Italy, 17-19 December 2014; pp. 1-6.

46. Elwert, T.; Goldmann, D.; Römer, F.; Buchert, M.; Merz, C.; Schüler, D.; Sutter, J. Current Developments and Challenges in the Recycling of Key Components of (Hybrid) Electric Vehicles. Recycling 2015, 1, 25-60. [CrossRef]

47. Ciez, R.E.; Whitacre, J.F. Examining different recycling processes for lithium-ion batteries. Nat. Sustain. 2019, 2, 148-156. [CrossRef]

48. Canals Casals, L.; Amante García, B.; Aguesse, F.; Iturrondobeitia, A. Second life of electric vehicle batteries: Relation between materials degradation and environmental impact. Int. J. Life Cycle Assess. 2017, 22, 82-93. [CrossRef]

49. Bräuer, S. They Not Only Live Once-Towards Product- Service Systems for Repurposed Electric Vehicle Batteries. In Proceedings of the MKWI 2016 - Multikonferenz Wirtschaftsinformatik; Nissen, V., Stelzer, D., Straßburger, S., Fischer, D., Eds.; Technische Universität Ilmenau: Ilmenau, Germany, 2016; Volume 4, pp. 1299-1310.

50. Xie, Y.; Yu, H.; Ou, Y.; Li, C. Business Model for Recycling Traction Battery. In Proceedings of the MEITA 2015-International Conference on Materials Engineering and Information Technology Applications, Qingdao, China, 28-29 November 2015; pp. 176-180.

51. Cusenza, M.A.; Guarino, F.; Longo, S.; Mistretta, M.; Cellura, M. Reuse of electric vehicle batteries in buildings: An integrated load match analysis and life cycle assessment approach. Energy Build. 2019, 186, 339-354. [CrossRef] 
52. Pagliaro, M.; Meneguzzo, F. Lithium battery reusing and recycling: A circular economy insight. Heliyon 2019, 5, 1-7. [CrossRef] [PubMed]

53. Ioakimidis, C.S.; Murillo-Marrodán, A.; Bagheri, A.; Thomas, D.; Genikomsakis, K.N. Life Cycle Assessment of a Lithium Iron Phosphate (LFP) Electric Vehicle Battery in Second Life Application Scenarios. Sustainability 2019, 11, 2527. [CrossRef]

54. Gaines, L. The future of automotive lithium-ion battery recycling: Charting a sustainable course. Sustain. Mater. Technol. 2014, 1, 2-7. [CrossRef]

55. Sonoc, A.; Jeswiet, J.; Soo, V.K. Opportunities to improve recycling of automotive lithium ion batteries. Procedia CIRP 2015, 29, 752-757. [CrossRef]

56. Sonoc, A.; Jeswiet, J. A review of lithium supply and demand and a preliminary investigation of a room temperature method to recycle lithium ion batteries to recover lithium and other materials. Procedia CIRP 2014, 15, 289-293. [CrossRef]

57. Liu, S.; Gong, D. Modelling and simulation on recycling of electric vehicle batteries-Using Agent approach. Int. J. Simul. Model. 2014, 13, 79-92. [CrossRef]

58. Tytgat, J. The recycling efficiency of Li-ion EV batteries according to the European Commission Regulation, and the relation with the end-of-life vehicles directive recycling rate. In Proceedings of the EVS27-2013 World Electric Vehicle Symposium and Exhibition, Barcelona, Spain, 17-20 November 2013; Volume 6, pp. 1039-1047.

59. Chagnes, A.; Pospiech, B. A brief review on hydrometallurgical technologies for recycling spent lithium-ion batteries. J. Chem. Technol. Biotechnol. 2013, 88, 1191-1199. [CrossRef]

60. Zeng, X.; Li, J.; Singh, N. Recycling of spent lithium-ion battery: A critical review. Crit. Rev. Environ. Sci. Technol. 2014, 44, 1129-1165. [CrossRef]

61. Chen, X.; Ma, H.; Luo, C.; Zhou, T. Recovery of valuable metals from waste cathode materials of spent lithium-ion batteries using mild phosphoric acid. J. Hazard. Mater. 2017, 326, 77-86. [CrossRef]

62. Heelan, J.; Gratz, E.; Zheng, Z.; Wang, Q.; Chen, M.; Apelian, D.; Wang, Y. Current and Prospective Li-Ion Battery Recycling and Recovery Processes. JOM J. Miner. Met. Mater. Soc. 2016, 68, 2632-2638. [CrossRef]

63. Ku, H.; Jung, Y.; Jo, M.; Park, S.; Kim, S.; Yang, D.; Rhee, K.; An, E.-M.; Sohn, J.; Kwon, K. Recycling of spent lithium-ion battery cathode materials by ammoniacal leaching. J. Hazard. Mater. 2016, 313, $138-146$. [CrossRef] [PubMed]

64. Moradi, B.; Botte, G.G. Recycling of graphite anodes for the next generation of lithium ion batteries. J. Appl. Electrochem. 2016, 46, 123-148. [CrossRef]

65. Zhang, W.; Liu, Z.; Xia, J.; Li, F.; He, W.; Li, G.; Huang, J. Preparing graphene from anode graphite of spent lithium-ion batteries. Front. Environ. Sci. Eng. 2017, 11, 1-8. [CrossRef]

66. Zhang, X.; Xue, Q.; Li, L.; Fan, E.; Wu, F.; Chen, R. Sustainable Recycling and Regeneration of Cathode Scraps from Industrial Production of Lithium-Ion Batteries. ACS Sustain. Chem. Eng. 2016, 4, 7041-7049. [CrossRef]

67. Li, H.; Corneal, L.M.; Standridge, C.R. Effects of acid concentration, temperature, and time on recycling of post-vehicle-application lithium-ion batteries of varying chemistries. Mater. Renew. Sustain. Energy 2015, 4, 1-5. [CrossRef]

68. Zeng, X.; Li, J. Innovative application of ionic liquid to separate $\mathrm{Al}$ and cathode materials from spent high-power lithium-ion batteries. J. Hazard. Mater. 2014, 271, 50-56. [CrossRef]

69. Raugei, M.; Winfield, P. Prospective LCA of the production and EoL recycling of a novel type of Li-ion battery for electric vehicles. J. Clean. Prod. 2019, 213, 926-932. [CrossRef]

70. Li, L.; Fan, E.; Guan, Y.; Zhang, X.; Xue, Q.; Wei, L.; Wu, F.; Chen, R. Sustainable Recovery of Cathode Materials from Spent Lithium-Ion Batteries Using Lactic Acid Leaching System. ACS Sustain. Chem. Eng. 2017, 5, 5224-5233. [CrossRef]

71. Xin, Y.; Guo, X.; Chen, S.; Wang, J.; Wu, F.; Xin, B. Bioleaching of valuable metals Li, Co, Ni and Mn from spent electric vehicle Li-ion batteries for the purpose of recovery. J. Clean. Prod. 2016, 116, 249-258. [CrossRef]

72. Cheng, Y.-P.; Li, Y.; Jiang, S.; Xie, H.-Q. The recovery of lithium cobalt oxides from spent Li-ion batteries and its electrochemical performances. In Proceedings of the ICPRE 2016-2016 IEEE International Conference on Power and Renewable Energy, Shanghai, China, 21-23 October 2016; pp. 204-208.

73. Diekmann, J.; Hanisch, C.; Froböse, L.; Schälicke, G.; Loellhoeffel, T.; Fölster, A.-S.; Kwade, A. Ecological Recycling of Lithium-Ion Batteries from Electric Vehicles with Focus on Mechanical Processes. J. Electrochem. Soc. 2017, 164, A6184-A6191. [CrossRef] 
74. Yun, L.; Linh, D.; Shui, L.; Peng, X.; Garg, A.; LE, M.L.P.; Asghari, S.; Sandoval, J. Metallurgical and mechanical methods for recycling of lithium-ion battery pack for electric vehicles. Resour. Conserv. Recycl. 2018, 136, 198-208. [CrossRef]

75. Lixandru, A.; Venkatesan, P.; Jönsson, C.; Poenaru, I.; Hall, B.; Yang, Y.; Walton, A.; Güth, K.; Gauß, R.; Gutfleisch, O. Identification and recovery of rare-earth permanent magnets from waste electrical and electronic equipment. Waste Manag. 2017, 68, 482-489. [CrossRef] [PubMed]

76. Bandara, H.M.D.; Mantell, M.A.; Darcy, J.W.; Emmert, M.H. Rare Earth Recycling: Forecast of Recoverable Nd from Shredder Scrap and Influence of Recycling Rates on Price Volatility. J. Sustain. Metall. 2015, 1, 179-188. [CrossRef]

77. Bandara, H.M.D.; Darcy, J.W.; Apelian, D.; Emmert, M.H. Value analysis of neodymium content in shredder feed: Toward enabling the feasibility of rare earth magnet recycling. Environ. Sci. Technol. 2014, 48, 6553-6560. [CrossRef]

78. Rademaker, J.H.; Kleijn, R.; Yang, Y. Recycling as a strategy against rare earth element criticality: A systemic evaluation of the potential yield of NdFeB magnet recycling. Environ. Sci. Technol. 2013, 47, 10129-10136. [CrossRef]

79. Yano, J.; Muroi, T.; Sakai, S. Rare earth element recovery potentials from end-of-life hybrid electric vehicle components in 2010-2030. J. Mater. Cycles Waste Manag. 2015, 18, 655-664. [CrossRef]

80. Elwert, T.; Goldmann, D.; Roemer, F.; Schwarz, S. Recycling of NdFeB Magnets from Electric Drive Motors of (Hybrid) Electric Vehicles. J. Sustain. Metall. 2016, 3, 108-121. [CrossRef]

81. Bulach, W.; Schüler, D.; Sellin, G.; Elwert, T.; Schmid, D.; Goldmann, D.; Buchert, M.; Kammer, U. Electric vehicle recycling 2020: Key component power electronics. Waste Manag. Res. 2018, 36, 311-320. [CrossRef]

82. Handley, C.; Brandon, N.P.; van der Vorst, R. Impact of the European Union vehicle waste directive on end-of-life options for polymer electrolyte fuel cells. J. Power Sources 2002, 106, 344-352. [CrossRef]

83. Kaushal, R.K.; Nema, A.K.; Chaudhary, J. Strategic exploration of battery waste management: A game-theoretic approach. Waste Manag. Res. 2015, 33, 681-689. [CrossRef] [PubMed]

84. Xing, Y.; Ma, E.W.M.; Tsui, K.L.; Pecht, M. Battery Management Systems in Electric and Hybrid Vehicles. Energies 2011, 4, 1840-1857. [CrossRef]

85. Hu, Y.; Cheng, H.; Tao, S. Retired Electric Vehicle (EV) Batteries: Integrated Waste Management and Research Needs. Environ. Sci. Technol. 2017, 51, 10927-10929. [CrossRef] [PubMed]

86. Liu, D.; Song, Y.; Li, L.; Liao, H.; Peng, Y. On-line life cycle health assessment for lithium-ion battery in electric vehicles. J. Clean. Prod. 2018, 199, 1050-1065. [CrossRef]

87. Richa, K.; Babbitt, C.W.; Gaustad, G. Eco-Efficiency Analysis of a Lithium-Ion Battery Waste Hierarchy Inspired by Circular Economy. J. Ind. Ecol. 2017, 21, 715-730. [CrossRef]

88. Richa, K.; Babbitt, C.W.; Gaustad, G.; Wang, X. A future perspective on lithium-ion battery waste flows from electric vehicles. Resour. Conserv. Recycl. 2014, 83, 63-76. [CrossRef]

89. Soo, V.K.; Peeters, J.R.; Paraskevas, D.; Compston, P.; Doolan, M.; Duflou, J.R. Sustainable aluminium recycling of end-of-life products: A joining techniques perspective. J. Clean. Prod. 2018, 178, 119-132. [CrossRef]

90. Xu, C.J.; Zhang, W.; He, W.; Li, G.; Huang, J.; Zhu, H. Generation and management of waste electric vehicle batteries in China. Environ. Sci. Pollut. Res. 2017, 24, 20825-20830. [CrossRef]

91. Ramoni, M.O.; Zhang, H.-C. End-of-life (EOL) issues and options for electric vehicle batteries. Clean Technol. Environ. Policy 2013, 15, 881-891. [CrossRef]

92. Foster, M.; Isely, P.; Standridge, C.R.; Hasan, M.M. Feasibility assessment of remanufacturing, repurposing, and recycling of end of vehicle application lithium-ion batteries. J. Ind. Eng. Manag. 2014, 7, 698-715. [CrossRef]

93. Kampker, A.; Heimes, H.H.; Ordung, M.; Lienemann, C.; Hollah, A.; Sarovic, N. Evaluation of a Remanufacturing for Lithium Ion Batteries from Electric Cars. Int. J. Mech. Mechatron. Eng. 2016, 10, 1922-1928.

94. Liu, W.-W.; Zhang, H.; Liu, L.-H.; Qing, X.-C.; Tang, Z.-J.; Li, M.-Z.; Yin, J.-S.; Zhang, H.-C. Remanufacturing cathode from end-of-life of lithium-ion secondary batteries by Nd:YAG laser radiation. Clean Technol. Environ. Policy 2016, 18, 231-243. [CrossRef]

95. Hannan, M.A.; Hoque, M.M.; Mohamed, A.; Ayob, A. Review of energy storage systems for electric vehicle applications: Issues and challenges. Renew. Sustain. Energy Rev. 2017, 69, 771-789. [CrossRef]

96. Wu, Z.; Wang, M.; Zheng, J.; Sun, X.; Zhao, M.; Wang, X. Life cycle greenhouse gas emission reduction potential of battery electric vehicle. J. Clean. Prod. 2018, 190, 462-470. [CrossRef] 
97. Riba, J.R.; López-Torres, C.; Romeral, L.; Garcia, A. Rare-earth-free propulsion motors for electric vehicles: A technology review. Renew. Sustain. Energy Rev. 2016, 57, 367-379. [CrossRef]

98. Ziemann, S.; Müller, D.B.; Schebek, L.; Weil, M. Modeling the potential impact of lithium recycling from EV batteries on lithium demand: A dynamic MFA approach. Resour. Conserv. Recycl. 2018, 133, 76-85. [CrossRef]

99. Wang, X.; Gaustad, G.; Babbitt, C.W.; Bailey, C.; Ganter, M.J.; Landi, B.J. Economic and environmental characterization of an evolving Li-ion battery waste stream. J. Environ. Manag. 2014, 135, 126-134. [CrossRef]

100. Wang, X.; Gaustad, G.; Babbitt, C.W.; Richa, K. Economies of scale for future lithium-ion battery recycling infrastructure. Resour. Conserv. Recycl. 2014, 83, 53-62. [CrossRef]

101. Price, B.; Dietz, E.; Richardson, J. Life cycle costs of electric and hybrid electric vehicle batteries and End-of-Life uses. In Proceedings of the EIT 2012-IEEE International Conference on Electro/Information Technology, Indianapolis, IN, USA, 6-8 May 2012; pp. 1-7.

102. Kibira, D.; Jain, S. Impact of Hybrid and Electric Vehicles on Automobile Recycling Infrastructure. In Proceedings of the WSC'11-2011 IEEE Winter Simulation Conference, Phoenix, AZ, USA, 11-14 December 2011; pp. 1072-1083.

103. Huth, C.; Kieckhäfer, K.; Spengler, T.S. Make-or-buy strategies for electric vehicle batteries-a simulation-based analysis. Technol. Forecast. Soc. Chang. 2015, 99, 22-34. [CrossRef]

104. Jansson, J.; Nordlund, A.; Westin, K. Examining drivers of sustainable consumption: The influence of norms and opinion leadership on electric vehicle adoption in Sweden. J. Clean. Prod. 2017, 154, 176-187. [CrossRef]

105. Garcia-Muiña, F.; González-Sánchez, R.; Ferrari, A.; Settembre-Blundo, D. The Paradigms of Industry 4.0 and Circular Economy as Enabling Drivers for the Competitiveness of Businesses and Territories: The Case of an Italian Ceramic Tiles Manufacturing Company. Soc. Sci. 2018, 7, 255. [CrossRef]

106. D'Adamo, I.; Falcone, P.M.; Ferella, F. A socio-economic analysis of biomethane in the transport sector: The case of Italy. Waste Manag. 2019, 95, 102-115. [CrossRef]

107. Garcia-Muiña, F.E.; González-Sánchez, R.; Ferrari, A.M.; Volpi, L.; Pini, M.; Settembre-Blundo, C.; Settembre-Blundo, D. Identifying the Equilibrium Point between Sustainability Goals and Circular Economy Practices in an Industry 4.0 Manufacturing Context Using Eco-Design. Soc. Sci. 2019, 8, 241. [CrossRef]

108. Un-Noor, F.; Padmanaban, S.; Mihet-Popa, L.; Mollah, M.N.; Hossain, E. A comprehensive study of key electric vehicle (EV) components, technologies, challenges, impacts, and future direction of development. Energies 2017, 10, 1217. [CrossRef]

109. Kawamoto, R.; Mochizuki, H.; Moriguchi, Y.; Nakano, T.; Motohashi, M.; Sakai, Y.; Inaba, A. Estimation of CO2 Emissions of Internal Combustion Engine Vehicle and Battery Electric Vehicle Using LCA. Sustainability 2019, 11, 2690. [CrossRef]

110. Ferrão, P.; Amaral, J. Assessing the economics of auto recycling activities in relation to European Union Directive on end of life vehicles. Technol. Forecast. Soc. Chang. 2006, 73, 277-289. [CrossRef]

111. Li, Y.; Lim, M.K.; Tan, Y.; Lee, S.Y.; Tseng, M.-L. Sharing economy to improve routing for urban logistics distribution using electric vehicles. Resour. Conserv. Recycl. 2019, 153, 1-13. [CrossRef]

112. Lieder, M.; Rashid, A. Towards circular economy implementation: A comprehensive review in context of manufacturing industry. J. Clean. Prod. 2016, 115, 36-51. [CrossRef]

113. Gaustad, G.; Krystofik, M.; Bustamante, M.; Badami, K. Circular economy strategies for mitigating critical material supply issues. Resour. Conserv. Recycl. 2018, 135, 24-33. [CrossRef]

114. Zubi, G.; Dufo-López, R.; Carvalho, M.; Pasaoglu, G. The lithium-ion battery: State of the art and future perspectives. Renew. Sustain. Energy Rev. 2018, 89, 292-308. [CrossRef]

115. Stoycheva, S.; Marchese, D.; Paul, C.; Padoan, S.; Juhmani, A.; Linkov, I. Multi-criteria decision analysis framework for sustainable manufacturing in automotive industry. J. Clean. Prod. 2018, 187, 257-272. [CrossRef]

116. Krishna Mohan, T.V.; Amit, R.K. Dismantlers' dilemma in end-of-life vehicle recycling markets: A system dynamics model. Ann. Oper. Res. 2018, 1-29. [CrossRef]

117. Rosa, P.; Terzi, S. Improving end of life vehicle's management practices: An economic assessment through system dynamics. J. Clean. Prod. 2018, 184, 520-536. [CrossRef]

118. Gu, H.; Liu, Z.; Qing, Q. Optimal electric vehicle production strategy under subsidy and battery recycling. Energy Policy 2017, 109, 579-589. [CrossRef] 
119. Hoyer, C.; Kieckhäfer, K.; Spengler, T.S. Impact of Mandatory Rates on the Recycling of Lithium-Ion Batteries from Electric Vehicles in Germany. In Proceedings of the LCE 2013-20th CIRP International Conference on Life Cycle Engineering, Singapore, 17-19 April 2013; pp. 543-548.

120. Khodier, A.; Williams, K.S.; Dallison, N. Challenges around automotive shredder residue production and disposal. Waste Manag. 2018, 73, 566-573. [CrossRef]

121. Cucchiella, F.; D’Adamo, I.; Rosa, P.; Terzi, S. Scrap automotive electronics: A mini-review of current management practices. Waste Manag. Res. 2016, 34, 3-10. [CrossRef] [PubMed]

122. Hoyer, C.; Kieckhäfer, K.; Spengler, T.S. Technology and capacity planning for the recycling of lithium-ion electric vehicle batteries in Germany. J. Bus. Econ. 2015, 85, 505-544. [CrossRef]

123. Zhou, F.; Wang, X.; Lim, M.K.; He, Y.; Li, L. Sustainable recycling partner selection using fuzzy DEMATEL-AEW-FVIKOR: A case study in small-and-medium enterprises (SMEs). J. Clean. Prod. 2018, 196, 489-504. [CrossRef]

124. Ai, N.; Zheng, J.; Chen, W.-Q. US end-of-life electric vehicle batteries: Dynamic inventory modeling and spatial analysis for regional solutions. Resour. Conserv. Recycl. 2019, 145, 208-219. [CrossRef]

125. Reinhardt, R.; Christodoulou, I.; Gassó-Domingo, S.; Amante García, B. Towards sustainable business models for electric vehicle battery second use: A critical review. J. Environ. Manag. 2019, 245, 432-446. [CrossRef]

126. Mayyas, A.; Steward, D.; Mann, M. The case for recycling: Overview and challenges in the material supply chain for automotive li-ion batteries. Sustain. Mater. Technol. 2018, 17, 1-13. [CrossRef]

127. Qiao, Q.; Zhao, F.; Liu, Z.; Hao, H. Electric vehicle recycling in China: Economic and environmental benefits. Resour. Conserv. Recycl. 2019, 140, 45-53. [CrossRef]

128. Tang, Y.; Zhang, Q.; Li, Y.; Li, H.; Pan, X.; Mclellan, B. The social-economic-environmental impacts of recycling retired EV batteries under reward-penalty mechanism. Appl. Energy 2019, 251, 1-16. [CrossRef]

129. Hendrickson, T.P.; Kavvada, O.; Shah, N.; Sathre, R.; Scown, C.D. Life-cycle implications and supply chain logistics of electric vehicle battery recycling in California. Environ. Res. Lett. 2015, 10, 1-10. [CrossRef]

(C) 2019 by the authors. Licensee MDPI, Basel, Switzerland. This article is an open access article distributed under the terms and conditions of the Creative Commons Attribution (CC BY) license (http://creativecommons.org/licenses/by/4.0/). 